\title{
Epidermal Growth Factor-Induced Epithelio-Mesenchymal Transition in Human Breast Carcinoma Cells
}

\author{
Margaret L. Ackland, Donald F. Newgreen, Masha Fridman, Mark C. Waltham, \\ Angela Arvanitis, Joseph Minichiello, John T. Price, and Erik W. Thompson
}

Deakin University (LA), Burwood, and The Murdoch Children's Research Institute (DN, JM), Parkville, and St. Vincent's Institute of Medical Research (MF, MW, AA, JP, ET), Fitzroy, and University of Melbourne, Department of Surgery (MW, AA, JP, ET), St. Vincent's Hospital, Melbourne, Australia

SUMMARY: PMC42-LA cells display an epithelial phenotype: the cells congregate into pavement epithelial sheets in which E-cadherin and $\beta$-catenin are localized at cell-cell borders. They abundantly express cytokeratins, although $5 \%$ to $10 \%$ of the cells also express the mesenchymal marker vimentin. Stimulation of PMC42-LA cells with epidermal growth factor (EGF) leads to epithelio-mesenchymal transition-like changes including up-regulation of vimentin and down-regulation of E-cadherin. Vimentin expression is seen in virtually all cells, and this increase is abrogated by treatment of cells with an EGF receptor antagonist. The expression of the mesenchyme-associated extracellular matrix molecules fibronectin and chondroitin sulfate proteoglycan also increase in the presence of EGF. PMC42-LA cells adhere rapidly to collagen I, collagen IV, and laminin-1 substrates and markedly more slowly to fibronectin and vitronectin. EGF increases the speed of cell adhesion to most of these extracellular matrix molecules without altering the order of adhesive preference. EGF also caused a time-dependent increase in the motility of PMC42-LA cells, commensurate with the degree of vimentin staining. The increase in motility was at least partly chemokinetic, because it was evident both with and without chemoattractive stimuli. Although E-cadherin staining at cell-cell junctions disappeared in response to EGF, $\beta$-catenin persisted at the cell periphery. Further analysis revealed that $\mathrm{N}$-cadherin was present at the cell-cell junctions of untreated cells and that expression was increased after EGF treatment. N- and E-cadherin are not usually coexpressed in human carcinoma cell lines but can be coexpressed in embryonic tissues, and this may signify an epithelial cell population prone to epithelio-mesenchymal-like responses. (Lab Invest 2003, 83:435-448).

$D$ uring metastatic progression, epithelial cancer cells leave the primary tumor, invade the interstitial tissue, enter blood vessels, and disseminate into secondary organs (Liotta, 1986; Price et al, 1997). The first steps of this process involve detachment of the cells from the epithelium, their adhesion to the extracellular matrix (ECM), balanced degradation of ECM components, and migration of cells into the stromal compartment. These changes are similar to those required for the migration of cells of epithelial origin during the highly regulated processes of embryonic morphogenesis (Birchmeier et al, 1996; Hay, 1995; Savagner et al, 1994), which involve the epitheliomesenchymal transition (EMT). During the EMT, the acquisition of migratory abilities in epithelial cells is

\section{DOI: 10.1097/01.LAB.0000059927.97515.FD}

Received January 7, 2003.

The first two authors contributed equally to this work. The present study was supported in part by The Cancer Council of Victoria, Murdoch Childrens Research Institute, Association for International Cancer Research, Victorian Breast Cancer Research Consortium, and the National Institutes of Health (R21-CA87244-01).

Address reprint requests to: Dr. E. Thompson, University of Melbourne, Department of Surgery (St. Vincent's Hospital), 29 Regent Street, Fitzroy, Victoria, 3065, Australia. E-mail: rik@medstv.unimelb.edu.au accompanied by the loss of epithelial features and the gain of mesenchymal characteristics (Birchmeier et al, 1996).

One of the most commonly used markers for the EMT in carcinoma cells is the unusual expression of the intermediate filament protein vimentin, which in mature tissues is normally restricted to mesenchymal cells (Gilles and Thompson, 1996; Hay, 1995). In a panel of human breast carcinoma cell lines, vimentin expression correlated with in vitro invasiveness (Thompson et al, 1992) and with loss of expression of epithelial traits including the cell-cell junctional molecules E-cadherin, ZO1, and desmoplakin (Sommers et al, 1989, 1991). Stromelysin (matrix metalloproteinase-3 [MMP-3])induced up-regulation of vimentin in a mouse mammary cell line model is accompanied by loss of E-cadherin, increased invasion, tumorigenicity, and metastasis (Lochter et al, 1997; Sternlicht et al, 1999, 2000). Similar changes have been reported in the NBT-II rat bladder carcinoma cell line in response to fibroblast growth factor-1 (FGF-1) and FGF-4/KFGF, transforming growth factor- $\alpha$ (TGF- $\alpha$ ), FGF-7/KGF, or collagen (Savagner et al, 1994). Vimentin expression has been associated with invasiveness of bladder (Savagner et al, 1994) and cervical (Gilles et al, 1996a, 1996b) cell lines. It also often accompanies poor prognostic features in various carci- 
noma types (reviewed in Gilles and Thompson, 1996). A direct link between the expression of vimentin itself and invasive behavior was shown in MCF-7 human breast cancer cells stably transfected with vimentin, in which transfectants showed increased invasive activity and motility (Hendrix et al, 1997).

Expression of the cell-cell adhesion molecule E-cadherin, on the other hand, correlates with epithelial differentiation and is seen in noninvasive carcinomas of bladder, breast, lung, and pancreas; invasiveness of dedifferentiated breast carcinoma cells has been prevented by transfection with E-cadherin cDNA (Birchmeier and Behrens, 1994; Frixen et al, 1991). Aside from their direct structural role in epithelial cell cohesiveness, cadherins play a signaling role that is partly mediated through modulation of the availability of $\beta$-catenin, a protein that links the cadherin complex to the actin cytoskeleton and that also influences transcriptional regulation by complexing with T-cell factor/lymphoid enhancing factor (Behrens, 2000). N-cadherin is expressed by embryonic neural and mesodermal epithelia (Hatta et al, 1987), and in prostate carcinoma studies it has been associated with progression, where it is expressed reciprocally with E-cadherin (Bussemakers et al, 2000; Tomita et al, 2000). In the embryo, however, $\mathrm{E}$ - and $\mathrm{N}$-cadherins can be coexpressed, with pathologic variations in the extent of coexpression (Newgreen et al, 1997). The actin cytoskeleton is also connected to the ECM through transmembrane adhesion molecules such as integrins, via linker and associated signaling molecules, and thus spatial concordance can be seen between the actin meshwork and ECM molecules (Parsons et al, 2000; Turner, 2000). Signals emanating from these adhesions can also drive the EMT (Somasiri et al, 2001).

An unequivocally epithelial cell line of human breast origin that could be induced to undergo EMT would be an important resource for the study of breast carcinoma EMT as well as EMT in general. We have used the PMC42 human breast carcinoma cell line, derived by $\mathrm{Dr}$. R. Whitehead and coworkers, to define a model of EMT in human breast carcinoma. The PMC42 cell line, thought to represent a mammary stem cell, has the capacity to develop into eight morphologic subtypes in culture after cloning (Whitehead et al, 1983a, 1983b, 1984). The cells grow both as a monolayer and as floating cords in papillary clusters (Whitehead et al, 1983a). They show proliferative responses to estrogen and progesterone (Whitehead et al, 1984), and they respond to EGF with increased cloning efficiency in semisolid agar and increased growth rate when growing as cords (Whitehead et al, 1983b). EGF also stimulates the attachment of floating cords of PMC42 cells (Whitehead et al, 1983a) and increases membrane expression of ECM proteins (Thorne et al, 1987). We characterize here a stable variant of PMC42 cells, PMC42-LA (Ackland et al, 2001), in which only 5\% to $10 \%$ of the cells express vimentin compared with $\sim 100 \%$ vimentin expression in parental PMC42 cells (E Thompson and D Newgreen, unpublished observations). In response to EGF, PMC42-LA cells underwent
EMT-like changes including acquisition of vimentin expression, redistribution and reduction of E-cadherin, assembly of extracellular fibronectin and chondroitin sulfate proteoglycan, and increased cell migration. In contrast to E-cadherin, $\beta$-catenin remained at the cell membrane after EGF-treatment; this was consistent with coexpression of $\mathrm{N}$-cadherin, which increased after EGF treatment. This model system thus provides an opportunity to dissect the molecular regulatory processes and effector molecules involved in EMT in a human mammary context and to study further its functional consequences.

\section{Results}

\section{Effect of EGF on Morphology and Molecular Expression in PMC42-LA Cells}

Cell Morphology. Under phase contrast microscopy, the free edge of PMC42-LA cell sheets in control medium were uniform with few outlying cells (Fig. 1A). The marginal cells formed regions of lamellar activity interspersed with retracted margins (Fig. 1C). Within 3 days of treatment with EGF $(10 \mathrm{ng} / \mathrm{ml})$, the edge of the cell sheet was less regular, with individual cells separated from the sheet (Fig. 1B). Lamellar activity with prominent ruffling occurred on most marginal cells (Fig. 1). To characterize these differences at the molecular level, we performed fluorescent molecular localization and Western analysis on a panel of cytoskeletal, adhesion, and ECM molecules after culture in the presence or absence of EGF.

Intermediate Filament Molecules. Under confluent conditions, and in the absence of EGF, between $5 \%$ and $10 \%$ of PMC42-LA cells expressed vimentin (Fig. $2 A)$. This proportion of vimentin-positive cells persisted in the stock cultures maintained by routine passaging. These vimentin-positive cells showed bundles of vimentin filaments in a generally spindleshaped cell body, in contrast to the flatter polygonal vimentin-negative cells, and were most common at the free edge of the cell sheet. Exposure of cells to EGF concentrations of 1,10 , and $50 \mathrm{ng} / \mathrm{ml}$ EGF produced a maximal response in vimentin expression at $10 \mathrm{ng} / \mathrm{ml}$ EGF. Treatment of the cultures with EGF $(10 \mathrm{ng} / \mathrm{ml})$ for 3 or more days induced vimentin expression in virtually all of the cells (Fig. 2B), and increased levels were detectable by Western blotting
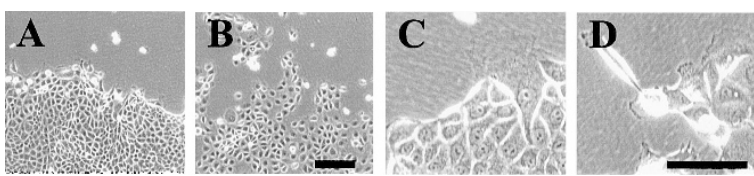

Figure 1.

Epidermal growth factor (EGF) effects on PMC42-LA cell morphology. PMC42-LA cells seen under phase contrast form a relatively homogeneous pavement of cells extending to the edge of the sheet (A). Treatment with EGF for 6 days led to the edge of the sheet becoming less regular, with gaps in the pavement and with outlying cells (B). Scale $=200 \mu \mathrm{m}$. Under control conditions, the edge of the cell sheet had alternating regions of lamellar spreading and cell retraction (C). EGF for 6 days increased the extent of lamellar extension and the degree of ruffling (D). Scale $=100 \mu \mathrm{m}$. 

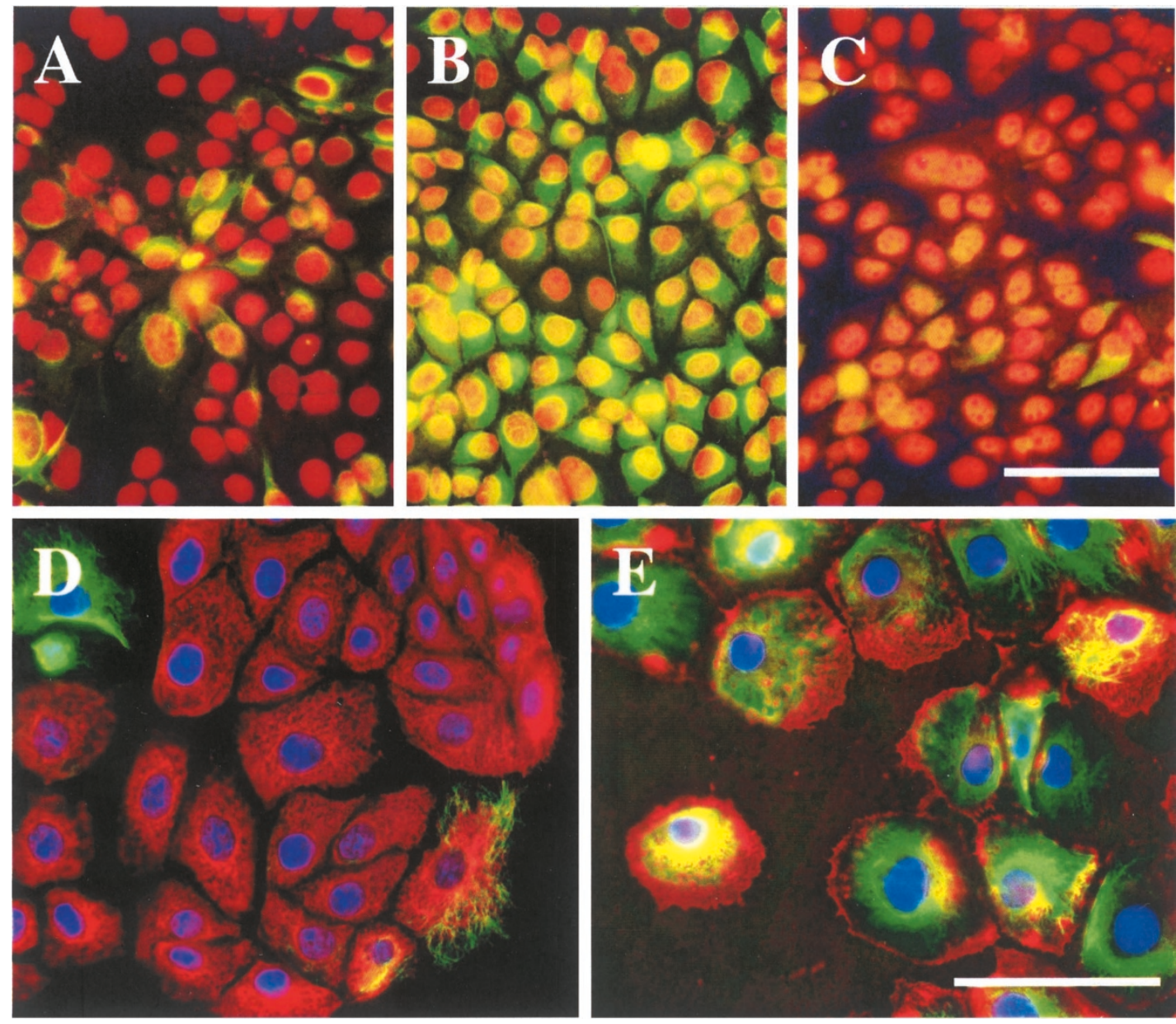

Figure 2.

Effects of EGF treatment on vimentin expression. Few PMC42-LA cells grown at high density for 3 days in control medium (A) showed vimentin immunoreactivity (green). Inclusion of $10 \mathrm{ng} / \mathrm{ml}$ EGF (B) induced vimentin expression in almost all cells. Inclusion with EGF of $2 \mu \mathrm{m}$ of the EGF receptor inhibitor AG1478 (C) inhibited the induction of vimentin. Nuclei (A to C) were stained with propidium iodide (red). Double labeling with pan-cytokeratin antibody (red) and vimentin (green) showed in control medium (D) that most cells were keratin positive/vimentin negative. After EGF treatment (E), most cells were positive for both keratin and vimentin. Nuclei (D and E) were stained with Hoechst 6024 (blue). Scale $=100 \mu \mathrm{m}$.

(Fig. 3B). Simultaneous treatment with EGF $(10 \mathrm{ng} / \mathrm{ml})$ and the EGF receptor kinase inhibitor AG1478 $(2 \mu \mathrm{M})$ blocked EGF induction of vimentin in the PMC42-LA cells (Fig. 2C). To determine the reversibility of the EGF-stimulated vimentin expression, PMC42-LA cells were treated with $10 \mathrm{ng} / \mathrm{ml}$ EGF for 3 days and then control medium for 3,5 , or 7 subsequent days. There was essentially no loss of staining after 3 days, approximately $10 \%$ loss after 5 days, and approximately $25 \%$ loss in the proportion of vimentin-positive cells in these cultures, relative to cells maintained in EGF for a total of 10 days.

In postembryonic cells, cytokeratins are the epithelial counterpart of vimentin; therefore, we also examined the effects of EGF on cytokeratins. Double immunostaining of untreated cells revealed that approximately $98 \%$ of the cells expressed cytokeratin and most, but not all, of the vimentin-positive cells in the untreated cultures coexpressed cytokeratin (Fig. 2D). Cells treated with EGF for 3 days coexpressed vimentin and cytokeratin (Fig. 2E). Western blot analysis was performed to measure the levels of various cytokeratins in extracts from PMC42-LA cells in control medium and in those treated with EGF for 4 days. A band of size $45 \mathrm{kDa}$, the predicted size for keratin 18, was detected in extracts from both EGF-treated and untreated cells (Fig. 3A; Lanes 1 and 2), with no difference in band intensities between EGF-treated and control cells. A broad band of size 43 to $45 \mathrm{kDa}$ was present in the MCF-7 cell lysate (Lane 3) and absent in the MDA-MB-231 cell lysate (Lane 4), consistent with the known expression pattern of keratin 18 in these cell lines.

Cell-Cell Adhesion Molecules. Another important characteristic that distinguishes epithelial from mesenchymal cells is the cell junctional complexes formed by homotypic cell adhesion molecules, principally the cadherins. E-cadherin was localized to cell junctions in most PMC42-LA cells, with some perinuclear cytoplasmic labeling (Fig. 4A). EGF treatment resulted in a reduction of E-cadherin immunoreactivity (Fig. 4B). Although $\mathrm{N}$-cadherin was also localized to cell boundaries and to the perinuclear cytoplasm in untreated PMC42-LA cells (note: N-cadherin in this latter 


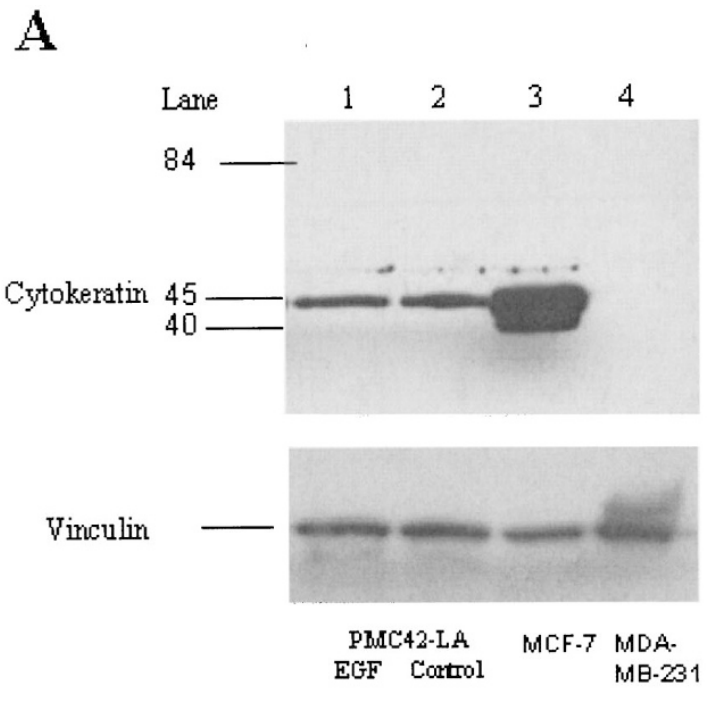

\section{B}
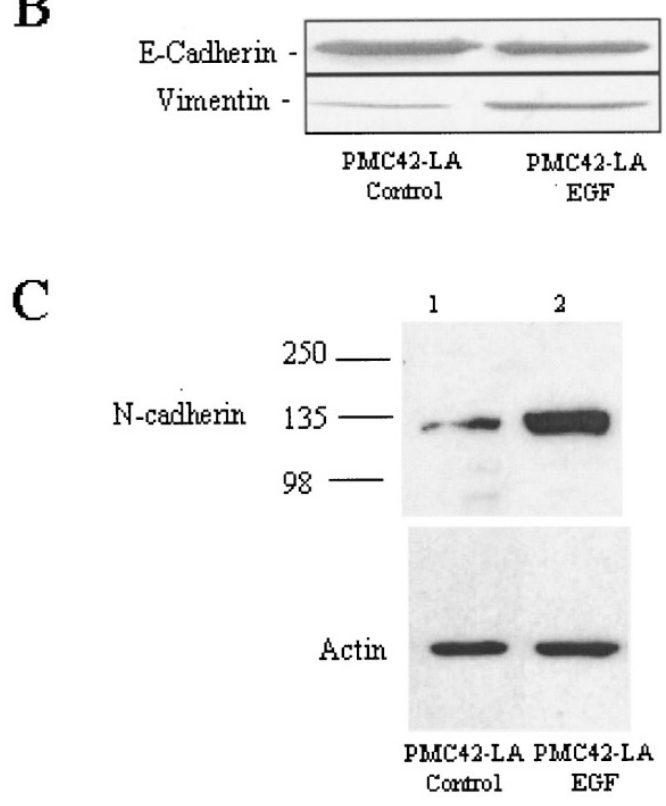

Figure 3.

Effect of EGF on levels of specific markers. Cells were cultured for 3 days in the absence (control) or presence of $10 \mathrm{ng} / \mathrm{ml} \mathrm{EGF,} \mathrm{after} \mathrm{which} \mathrm{whole} \mathrm{cell} \mathrm{lysates}$ collected in RIPA buffer were subjected to Western blot analysis and probed to detect (A) pan-cytokeratin. Lane $1=\mathrm{MW}$ markers; Lane 2 = cell extracts from PMC42-LA treated with EGF $(10 \mathrm{ng} / \mathrm{ml}$ for 3 days); Lane $3=$ untreated PMC42-LA cell extracts; Lane $4=$ cell extracts from MCF-7 cells (positive control); Lane 5 = extracts from MDA-MB231 cells (negative control). To indicate the relative levels of protein present in extracts, the membrane was probed with an antibody to vinculin. (B) E-cadherin and vimentin detection. (C) $\mathrm{N}$-cadherin detection. Relative levels of protein were determined by reprobing for actin. The results indicate an EGF-induced decrease in cytokeratin and $\mathrm{E}$-cadherin levels and an increase in vimentin and $\mathrm{N}$-cadherin levels.

location was poorly labeled with GC-4 mAb compared with the 808-827 polyclonal antibody) (Fig. $4 C)$, in contrast to E-cadherin, this was increased by EGF treatment (Fig. 4D). $\beta$-catenin, a linker molecule between the cadherin molecules and the F-actin cytoskeleton, maintained a juxta-adhesion distribution in both control and EGF-treated cells (Fig. 4, E and F).
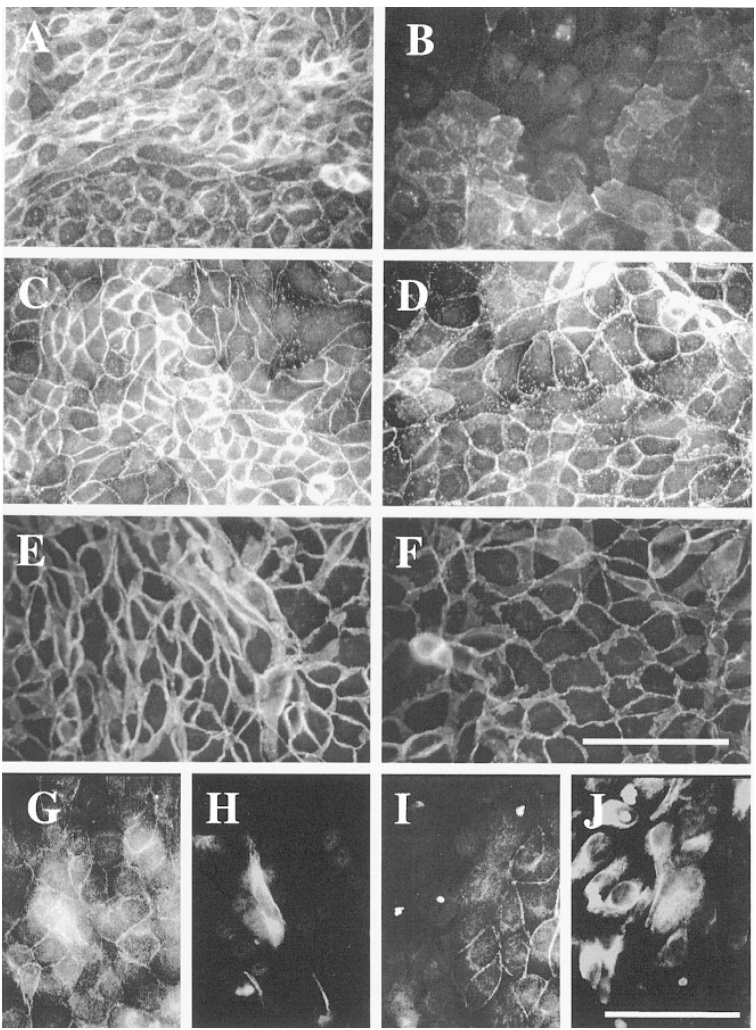

Figure 4.

Effect of EGF on the cell-cell adhesion complex. PMC42-LA cells were grown in Terasaki wells for 9 days in the absence $(A, C$, and $E$ ) or presence $(B, D$, and F) of $10 \mathrm{ng} / \mathrm{ml} \mathrm{EGF}$, then labeled with anti-E-cadherin (A and B), GC-4 anti-N-cadherin ( $\mathrm{C}$ and $\mathrm{D}$ ), or anti- $\beta$-catenin (E and F). (The GC-4 antibody most efficiently labels $\mathrm{N}$-cadherin located at junctions). Double-labeling of PMC42-LA cells for E-cadherin ( $G$ and $I$ ) and vimentin ( $H$ and $J$ ) after 4 days of growth in either control medium ( $\mathrm{G}$ and $\mathrm{H}$; same field) or EGF (I and J; same field) showed that these molecules were mutually exclusively expressed. Scale $=100 \mu \mathrm{m}$.

Spatial Relationship Between Expression of Vimentin and E-Cadherin. A clear inverse relationship was seen between expression of vimentin and E-cadherin (Fig. 4, G-J). This applied equally for the relatively sparse vimentin-positive cells in control cultures (Fig. 4, $G$ and $H$ ), and for the numerous vimentin-positive cells induced by EGF (Fig. 4, I and J). In the control conditions, it was especially clear that the few vimentin-positive cells lay on top of the sheet of E-cadherin-positive/vimentin-negative cells.

ECM Molecules. In addition to the cytoskeletal components, certain ECM components are also more highly expressed by mesenchymal cells. Fibronectin occurred as fibers around PMC42-LA cells, whereas chondroitin sulfate proteoglycan was distributed as coarse dots and fibers between the cells and as a fine stipple beneath the cells. In control PMC42-LA cell cultures, extracellular fibronectin staining (Fig. 5A) mapped closely to regions of cells that expressed vimentin (Fig. 5B), and the distribution and density of fibronectin immunoreactivity was dramatically upregulated with EGF treatment (compare Fig. 5, C and D). Similarly, labeling for chondroitin sulfate proteoglycan was up-regulated with EGF treatment (Fig. 5, E and F). 

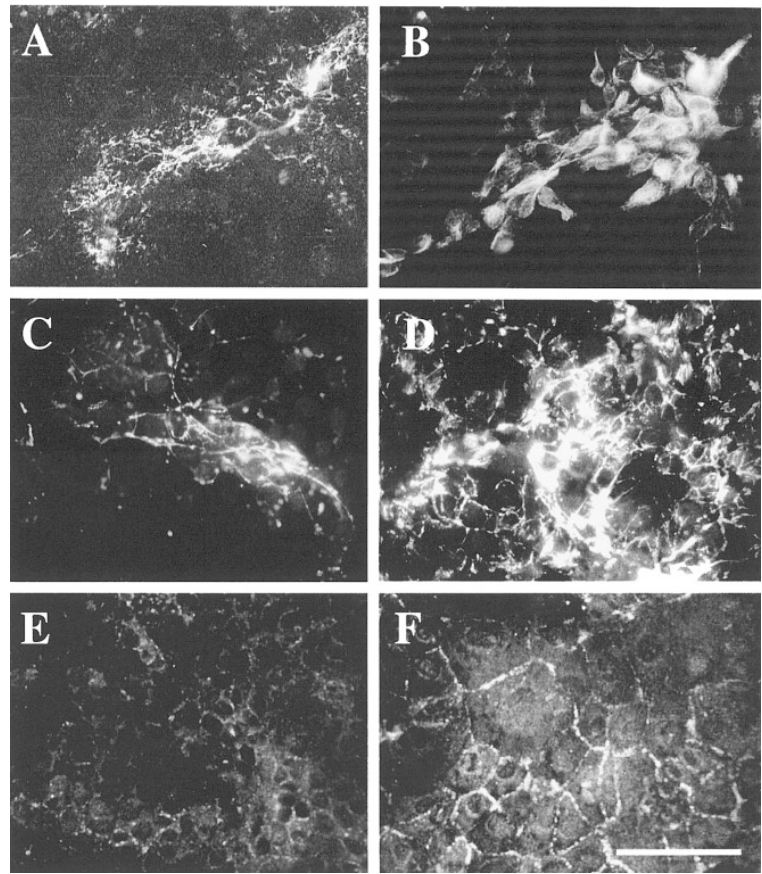

Figure 5.

Effect of EGF on extracellular matrix (ECM) of PMC42-LA cells. PMC42-LA cells were grown in Terasaki wells for 6 days in control medium and double labeled with anti-fibronectin (A) plus anti-vimentin (B, same field as A). Areas of maximal fibronectin deposition colocalized with groups of vimentin-positive cells. Compared with cells in control medium (C), $10 \mathrm{ng} / \mathrm{ml}$ EGF increased fibrillar fibronectin deposition (D). Likewise, chondroitin sulfate proteoglycan immunoreactivity was present in cultures in control medium (E) but was increased by EGF treatment (F). Scale $=100 \mu \mathrm{m}$.

\section{Effect of EGF on Adhesion and Motility of PMC42-LA Cells}

EGF Increases the Rate of Cell-ECM Adhesion. PMC42-LA cells that had been exposed to EGF for 6 days were dissociated and replated onto ECM substrates, and the rate of adhesion was measured. Control cells adhered rapidly to collagen type $\mathrm{I} \geq$ collagen type IV $\geq$ laminin-1, but fibronectin and vitronectin supported much slower adhesion (Fig. 6). However, by 12 hours, these cells were well attached to all substrates (data not shown). The EGF-treated cells showed the same hierarchy of preference for the ECM molecules tested, but EGF stimulated adhesion to collagen I $(p<0.0001$ at 15 and 30 minutes, $p<$ 0.001 at 60 minutes). Only the initial rate of adhesion was increased by EGF for collagen IV $p=0.006$ at 15 minutes, $p<0.0001$ at 30 minutes, no difference at 60 or 120 minutes) and laminin $(p=0.0007$ at 15 minutes). EGF effects were less apparent with the fibronectin and vitronectin substrates, which were not preferred by the PMC42-LA cells, such that slight but significant differences were only detected at $60(p<$ $0.0001)$ and $120(p=0.019)$ minutes for fibronectin and only at 30 minutes $(p=0.042$ ) for vitronectin (Fig. 6). These EGF effects are consistent with the increased adhesive dynamics of mesenchymal cells.

EGF Increases Cell Migration. Because mesenchymal features are often accompanied by increased migratory potential, we examined the effects of EGF
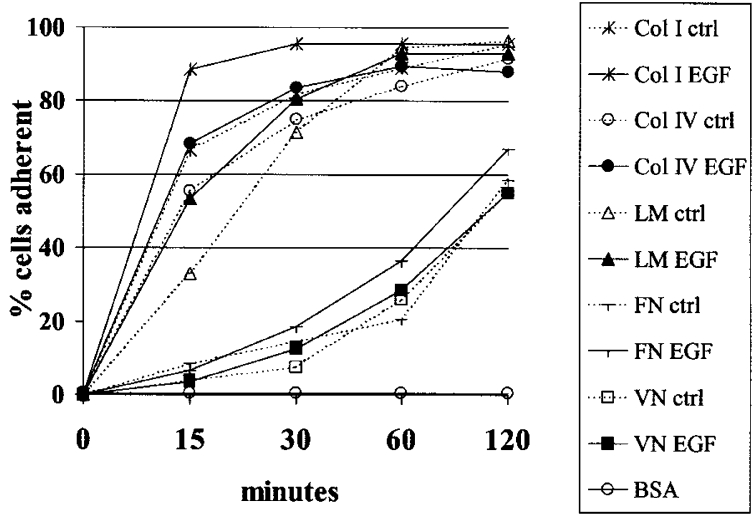

Figure 6.

Effect of EGF on cell-ECM adhesion. Dissociated PMC42-LA cells previously treated with control (ctr) or EGF (10 ng/ml) for 6 days were scored for initial adhesion rate to substrates of adsorbed collagen I, collagen IV, laminin-1, fibronectin, and vitronectin, with BSA as the negative control. Note that EGF increased the rate of adhesion in general but did not favor adhesion to any single ECM molecule and did not affect the level of adhesion attained after several hours.

on PMC42-LA cell migration. In the first set of experiments, PMC42-LA cells were examined for both directed migration (fetal bovine serum [FBS] chemoattractant) or undirected migration (BSA only, no chemoattractant gradient) in 48-well microchemotaxis chambers. As shown in Figure 7, overnight treatment

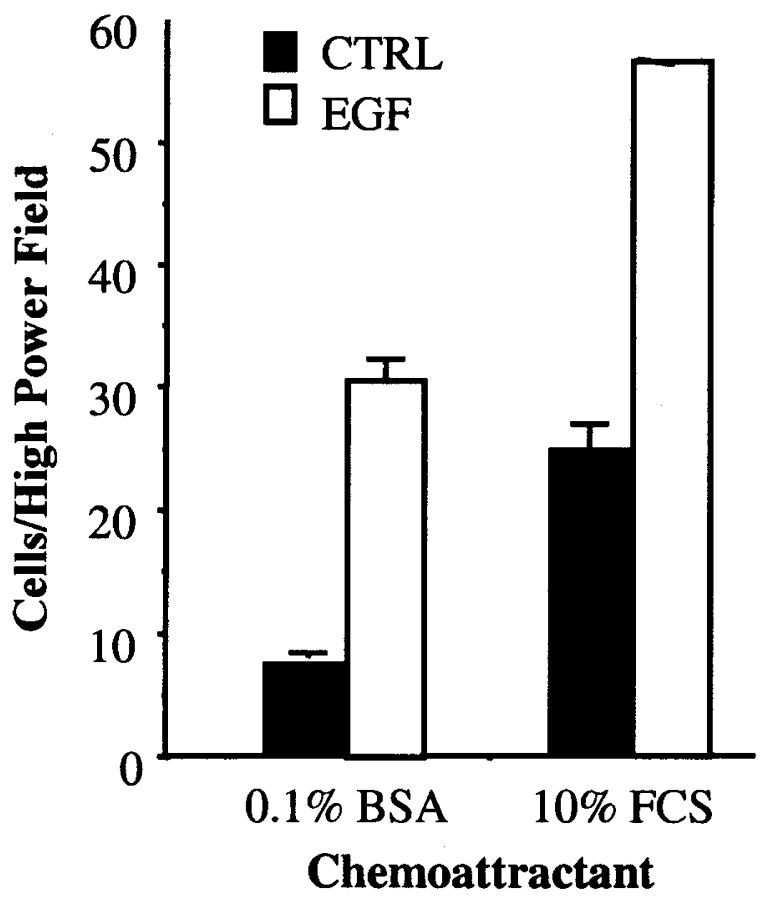

Figure 7.

Effect of EGF on PMC42-LA migration. PMC42-LA cells were grown to 40\% to $50 \%$ confluence and treated with $10 \mathrm{ng} / \mathrm{ml} \mathrm{EGF}$ in RPMl $/ 10 \%$ fetal bovine serum (FBS) for 24 hours. Cell migration was then assessed using the 48-well microchemotaxis chamber as described in "Materials and Methods" (results depict mean $\pm \mathrm{SD})$. EGF significantly increased the background migration $\left(0.1 \%\right.$ BSA; $\left.p=2.08 \times 10^{-5}\right)$ as well as the chemomigration of the PMC-42-LA cells toward $10 \%$ FBS $\left(p=3.11 \times 10^{-5}\right)$ on collagen IV-coated and collagen I-coated (data not shown) filters. 
with EGF significantly increased the migration of the PMC42-LA cells in both scenarios to a similar extent. To correlate the expression of vimentin more closely with increased cell migration, we further examined both vimentin expression and migration of PMC42-LA cells in Transwell chambers after different durations of EGF treatment. As seen in Figure 8A, EGF-induced staining for vimentin was evident in certain subpopu-
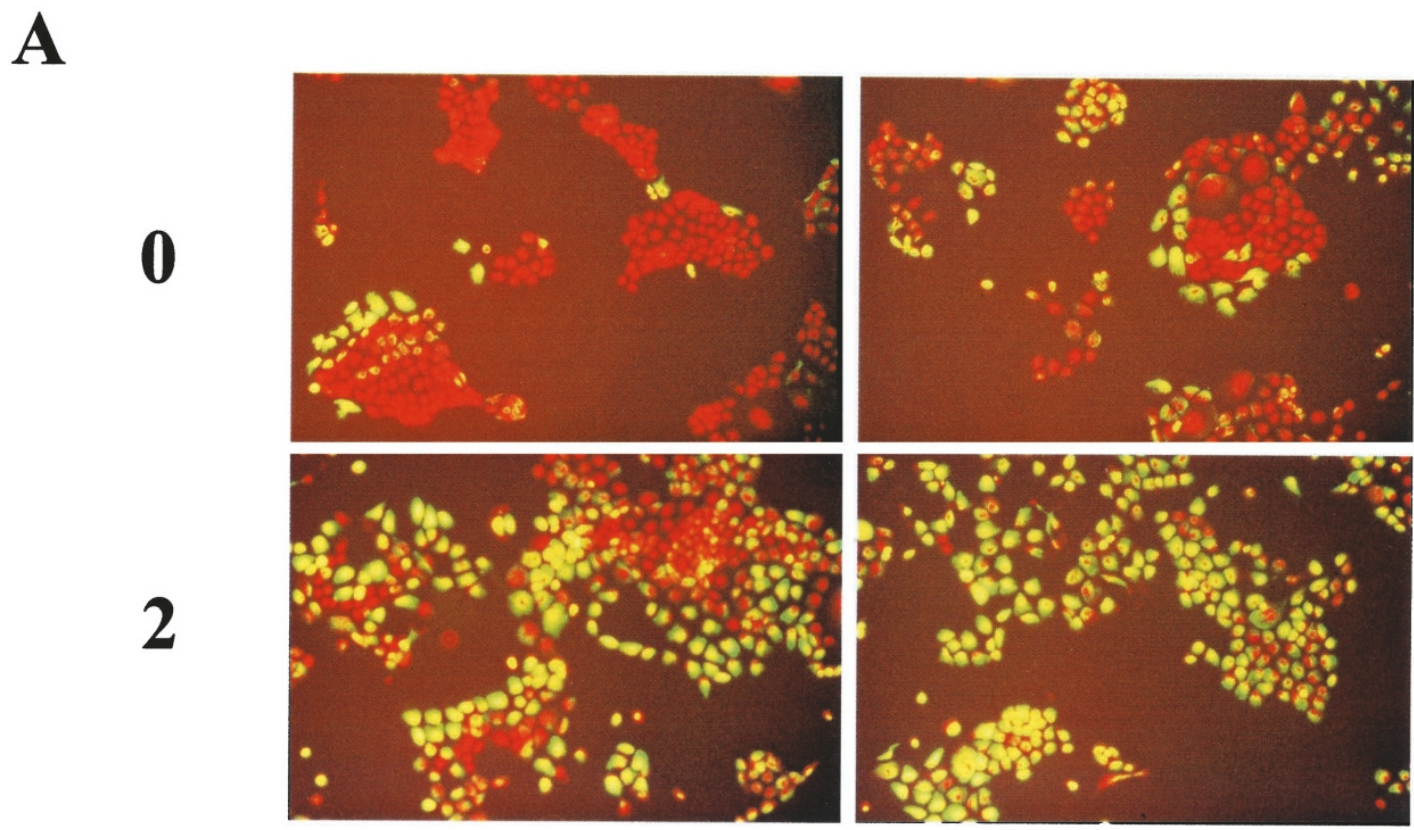

1

3

B

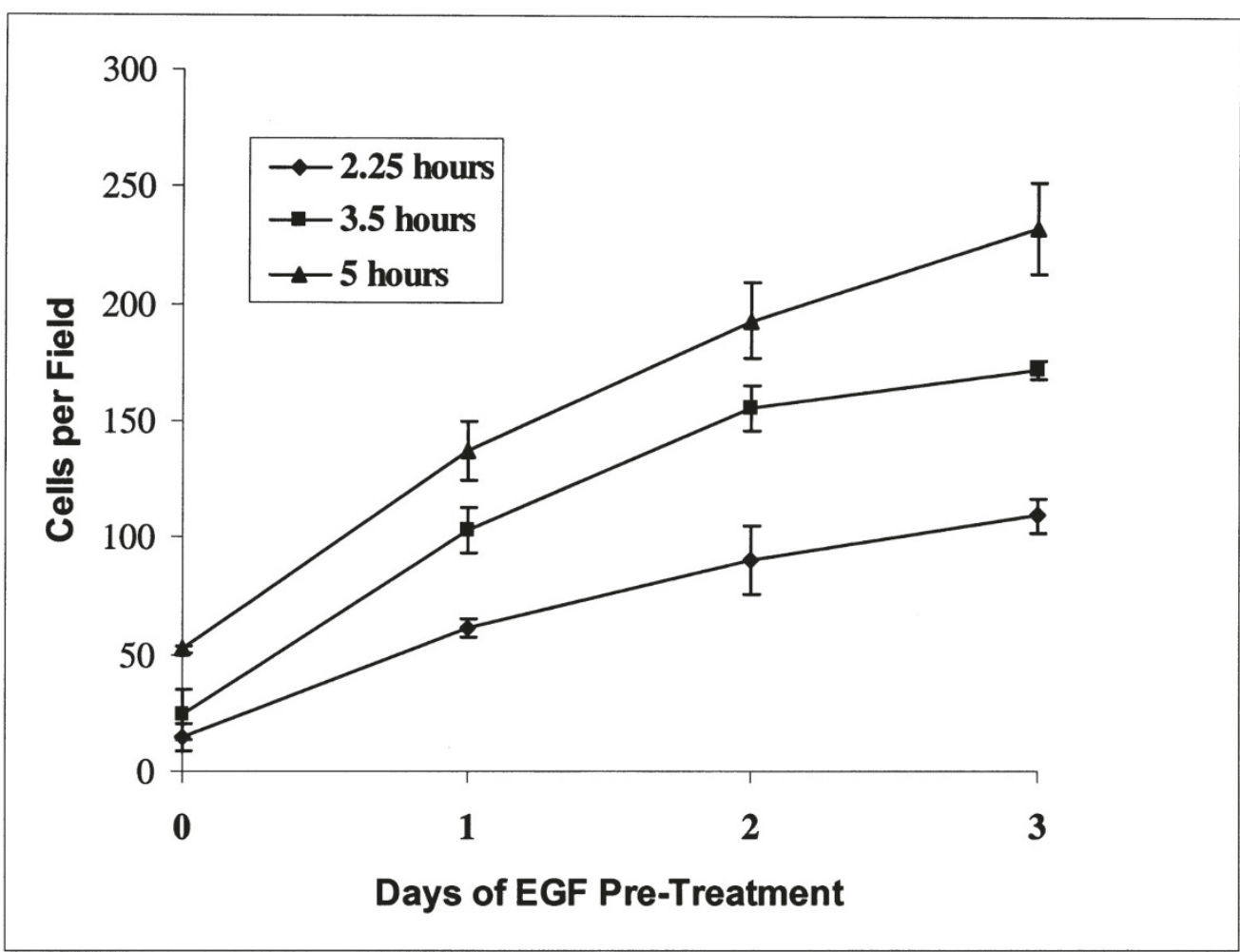

Figure 8.

Effect of EGF on migration in relation to vimentin expression. PMC42-LA cells were treated for $0,1,2$, or 3 days with EGF (10 ng/ml) and analyzed for vimentin expression (A) and chemomigration toward fibroblast-conditioned medium (B). Length (days) of EGF treatment is indicated by the numbers in $A$. Length of time in the Transwell assay is indicated in the inset of B. Note the corresponding increases in both vimentin expression and chemomigration with EGF treatment time. 
lations by 1 day, with increasingly more of the cells staining after 2 and 3 days, respectively. Vimentin was up-regulated first in cells at the periphery of culture islands, although some internal cells also showed early induction. The migratory potential of these cells in the Transwell assay increased accordingly (Fig. 8B), with EGF-treated cells being significantly more motile at each assay duration ( $\rho<0.001$, ANOVA).

\section{Discussion}

\section{EGF Has Multiple Roles in Cancer}

EGF plays important roles in cell survival, proliferation, migration, and differentiation as well as tumorigenesis and carcinoma progression (Cohen et al, 1998; Hackel et al, 1999). In breast carcinoma, overexpression of EGF receptor correlates with tumor progression and poor prognosis (Harris et al, 1992); thus our studies on EGF will have clinical relevance. Indeed, we recently showed motility responses in MDA-MB-231 cells, which have maximum proliferation through Ki-Ras activation and hence no additional proliferation in response to EGF (Price et al, 1999). This indicates that EGF can have important functional consequences for cells in advanced tumors beyond proliferation. The capacity of EGF to stimulate an EMT was also previously seen in NBT-Il rat bladder carcinoma cells (Savagner et al, 1994), and more importantly, Gilles et al (1999) showed that human mammary MCF10A cells treated with EGF expressed vimentin in association with migration at the cell culture edge.

\section{EGF Effects on PMC42-LA Cells Resemble EMT}

Molecular Expression. EMT involves a cadre of changes typically involving down-regulation of cellcell adhesion, alteration in cell-matrix adhesion, changes in cell polarity and cytoskeletal status, alterations in the ECM molecules synthesized and assembled, and up-regulation of synthesis and activity of extracellular proteases (Hay, 1995). The EMT concept originated from studies of development, where it is a tightly controlled mechanism of tissue morphogenesis in which cells within an epithelium are rapidly remodeled and redistributed by subsequent cell migration, as in gastrulation (Viebahn, 1995) and neural crest migration (Duband et al, 1995). Even in more mature cells, EMT functional changes can still occur, for example, in the healing of epithelial wounds (Warn et al, 2001; Zavadil et al, 2001), in the trophoblast during placentation (Vicovac and Aplin, 1996), and in certain adult pathologies such as cataract formation (Hales et al, 1999) and renal interstitial fibrosis associated with diabetic nephropathy (Yang and Liu, 2001). The notion of the EMT process as a major mechanism for carcinoma metastasis is not new but is gaining acceptance (Boyer et al, 2000). In the current study, we showed that PMC42-LA cells express markers that are characteristic of a well-differentiated breast carcinoma, for example, cytokeratin 18, which is also present in the relatively differentiated MCF-7 line and absent in MDA MB231, a more mesenchymal line. PMC42-LA can be induced to undergo many aspects of EMT in response to EGF treatment including down-regulation of the cell adhesion marker E-cadherin, increases in fibronectin and chondroitin sulfate proteoglycan assembly, and up-regulation of vimentin expression.

The reduction of E-cadherin seen after EGF treatment is typical of other cellular EMT systems (eg, NBT-II, ScP-2 cell lines) and consistent with the lack of E-cadherin in other human breast carcinoma cell lines (Nieman et al, 1999; Sommers et al, 1994). Indeed, correlations in clinical specimens between loss of E-cadherin and poor outcome (Welch et al, 2000) are more consistent than those with gain of vimentin (reviewed in Gilles and Thompson, 1996). Cadherin is also down-regulated in embryonic EMT; however, this is not restricted to $\mathrm{E}$-cadherin, because $\mathrm{N}$-cadherin is reduced in neural crest EMT (Duband et al, 1995). We found $\mathrm{N}$-cadherin to be expressed in control PMC42-LA cells and in increased amounts after treatment with EGF. Our observations showing coexpression of $\mathrm{E}$ - and $\mathrm{N}$-cadherin in untreated cells are different from previous studies of other breast cancer cell lines, in which $\mathrm{N}$-cadherin was selectively expressed by E-cadherin-negative invasive human breast carcinoma cell lines and predicted invasiveness even in the absence of vimentin (Hazan et al, 1997; Nieman et al, 1999). N-cadherin was found to promote adhesion of breast cancer cells to stromal cells (Hazan et al, 1997) and transfection of N-cadherin into MCF-7 cells, such that $\mathrm{N}$-cadherin and E-cadherin were coexpressed, causing increased migration, invasion, and metastasis (Hazan et al, 2000). In prostatic carcinoma, $\mathrm{N}$-cadherin was expressed reciprocally to E-cadherin in both cell lines and clinical specimens (Bussemakers et al, 2000). Coexpression of $\mathrm{E}$ - and $\mathrm{N}$ - cadherin by PMC42-LA cells under basal conditions is clearly unusual and could predispose these cells to their EMT-like responses to EGF. It may be that the relative levels of expression of $\mathrm{E}$-cadherin and $\mathrm{N}$-cadherin are more significant than the absolute levels of expression of both these cell-adhesion molecules.

One of the major responses to EGF treatment seen in PMC42-LA cells was the induction of vimentin. Vimentin is a major hallmark of mesenchymal cells (Steinert and Roop, 1988). Vimentin has been reported in the carcinoma component of a variety of human epithelial tumors including cervical, renal, thyroid, ovarian, pulmonary, and prostatic carcinomas, but it has been studied most in the breast, in which it associates with high growth fraction, poor nuclear grade, lack of estrogen receptor, and in some cases poor survival, the latter being controversial (reviewed in Gilles and Thompson, 1996; Seshadri et al, 1996). Vimentin expression has also been associated with invasiveness of bladder (Savagner et al, 1994) and cervical carcinoma (Gilles et al, 1996a, 1996b). The change of a vimentin-negative cell to a vimentinpositive cell is a reasonable indicator for at least some aspects of EMT, especially in cells originating from postembryonic epithelia; however, expression of vimentin does not of itself preclude the cell from being epithelial as judged by adhesion, basal lam- 
ina, and polarization criteria. For example, many early embryonic epithelia also express vimentin, including neural and mesodermal epithelia (Erickson et al, 1987; Page, 1989; Viebahn et al, 1988). Interestingly these vimentin-positive epithelia show the most dynamic subsequent cellular fates, including overt EMT. Although NMuMG mouse mammary cells are epithelial in nature, they coexpress vimentin and keratins under control conditions, and they lose E-cadherin and gain fibronectin expression when stimulated to undergo an EMT by TGF. Various other cultured primary epithelial cells also coexpress vimentin and keratins (Franke et al, 1979), and we recently characterized a mouse mammary carcinoma system in which both noninvasive/metastatic $67 \mathrm{NR}$ cells and invasive/metastatic $4 \mathrm{~T} 1.2$ cells expressed vimentin; but the $4 \mathrm{~T} 1.2$ cells showed additional proteolytic differences including capacity to activate MMP-2 and secretion of MMP-9 (Tester et al, 2001). In the PMC42 system, the EGF-induced mesenchymal phenotype includes induction of vimentin.

PMC42-LA cells responded to EGF with increased assembly of fibronectin and chondroitin sulfate proteoglycan. This is consistent with a previous study in which EGF treatment of PMC42 cells was found to increase the synthesis of $\left[{ }^{35} \mathrm{~S}\right]$ methionine-labeled proteins, suggested to be laminin and fibronectin (Thorne et al, 1987). These ECM molecules are characteristic of the mesenchymal compartment in both embryonic and adult tissues.

Adhesive and Migratory Behavior. After EGF treatment of PMC42-LA cells, significant changes in expression of the markers discussed above were accompanied by increased rates of adhesion to ECM molecules and by increased migratory capacity. The increases in adhesion rate were not confined to one or a few ECM molecules, suggesting that EGF must either up-regulate numerous ECM receptors (eg, integrins) in parallel or be acting at a common level downstream of these receptors. There was a close correlation between the degree of vimentin positivity in the cultures and their migration in the Transwells. Cell migration has a central role in metastasis, and the majority of invasive and metastatic human breast cancer cell lines exhibit mesenchymal characteristics typified by vimentin expression, reduced or absent keratin staining, a defective E-cadherin/ $\beta$-catenin axis (Gilles et al, 1997; Sommers et al, 1989, 1994), and increased motility, invasiveness, and metastatic potential (Thompson et al, 1992).

\section{EMT as a Unifying Concept in the Diagnosis and Understanding of Metastatic Cancer}

Although the likelihood that EMT changes are associated with tumor progression is becoming well accepted, the molecular and cellular events that initiate and mediate these changes have not been clearly elucidated. The control and coordination of molecular and biofunctional changes contributing to EMT has been investigated using early embryonic primary cells, most notably avian corneal epithelium (Hay, 1995) and avian neural epithelium/neural crest cells (Minichiello et al, 1999; Newgreen and Minichiello, 1995, 1996). These have the advantage of stereotypic developmental progression, but the low cell numbers is a disadvantage, especially for biochemical studies. Significant parallels between developmental systems and cancer can be made, and factors such as Snail, a homolog of the zinc finger protein Slug that regulates EMT in avian gastrulation and neural crest migration (Nieto et al, 1994), were found to cause aspects of the EMT in mammalian carcinoma cells (Savagner et al, 1997). In particular, recent studies have revealed that Snail binds to and represses the promoter of E-cadherin (Batlle et al, 2000; Cano et al, 2000), leading to loss of cell-cell adhesive capability and to increased invasiveness. Similarly, the transcription factor ETS-1, seen in embryonic EMT (Fafeur et al, 1997), is consistently expressed by invasive human mammary carcinoma cell lines (Gilles et al, 1997). Among ETS-1 targets for activation is the stromelysin-1 (MMP-3) gene, and this extracellular endoprotease can cleave E-cadherin, leading to eventually irreversible EMT and invasive alterations in mouse mammary cells (Lochter et al, 1997; Sternlicht et al, 1999, 2000). Likewise, members of the TGF- $\beta$ family of growth factors are involved in many embryonic EMTs (Hay, 1995; Liem et al, 1995; McEarchern et al, 2001; Miettinen et al, 1994; Nakajima et al, 2000; Piek et al, 1999; Runyan et al, 1992) and in metastatic progression in many systems (Oft et al, 1996; Zavadil et al, 2001). Recently Janda et al (2002) elegantly dissected signaling processes for regulation of the EMT in EpRas mouse mammary epithelial cells in response to TGF- $\beta$, showing that PI3K signals mediated a scattering phenotype while MAP kinase pathways mediated EMT. Whether this is generalizable to other systems or specific to their system remains to be determined. We were unable to stimulate or modulate EMT in PMC42-LA cells with TGF- $\beta$ or BMP-4 (E. Thompson and D. Newgreen, unpublished observations).

Cells of different lineages or in different contexts may use different molecules to execute the abovementioned changes in cellular functions, although these molecules are often members of the same families. Thus, all EMTs cannot be identified on the basis of alteration of a single molecular marker; nevertheless all EMTs show a core of common or related molecular changes. New markers that predict a propensity for EMT, or that allow us to more specifically identify EMT-derived breast carcinoma cells in the tumor vicinity, could have a dramatic impact on breast carcinoma prognosis. It may be that diagnostic criteria in the future will rest on a consensus of markers bearing in mind the cell lineage, rather than attempting a definition of EMT based on a single marker. In fact, characterization of the mesenchymal phenotype that results from the EMT is becoming better defined at the multimolecular level, with a number of recent largescale gene expression profiling studies including dif- 
ferent human breast carcinoma cell lines with either epithelial (eg, MCF-7, T47D, Zr-75-1) or mesenchymal (eg, MDA-MB-231, MDA-MB-453, BT-549, Hs578T) characteristics (Perou et al, 1999; Ross et al, 2000; Zajchowski et al, 2001). In each case, the expression of a host of mesenchymal gene products has been reported, including collagens, SPARC, fibronectin, discoidin domain receptor, TGF- $\beta$, connective tissue growth factor, and MMPs. Furthermore, a subset comprising 24 gene products, many of which reflect epithelial or mesenchymal traits, was recently found to be highly predictive of in vitro invasiveness of unknown human mammary breast carcinoma cells (Zajchowski et al, 2001). Gene array profiling has also shown important differences between SMADdependent and -independent regulation of EMT end points in TGF- $\beta$-treated human keratinocytes (Zavadil et al, 2001). Such analysis is underway in the PMC42-LA system. This system therefore provides a valuable resource to further explore the regulation of the EMT and its significance in human breast carcinomas, through cell biologic, biochemical, molecular genetic, and microarray technologies.

\section{Materials and Methods}

\section{Cells and Reagents}

The PMC42 cell line, originally derived from a pleural effusion (Whitehead et al, 1983a), was obtained from Dr. Rob Whitehead, Ludwig Institute of Cancer Research, Melbourne, Australia. We used a stable variant of the parental PMC42 cell line, designated PMC2-LA (Ackland et al, 2001). MCF-7 and MDA-MB-231 cells were originally from the American Type Culture Collection (Rockville, Maryland) and provided by the Lombardi Cancer Center Tissue Shared Resource, Georgetown University Medical Center (Washington, District of Columbia). Cells were cultured in $75-\mathrm{cm}^{2}$ culture flasks (either Cellstar Greiner, Interpath Services, Melbourne, Australia, or Nunclon, Medos, Melbourne, Australia) in RPMI 1640 (Trace Biosciences, Melbourne, Australia) supplemented with 10\% FBS (CSL, Melbourne, Australia) at $37^{\circ} \mathrm{C}$ in a $5 \% \mathrm{CO}_{2}$ atmosphere. The cells were passaged when confluent using $0.05 \%$ trypsin-EDTA (CSL or Sigma-Aldrich, Castle Hill, New South Wales, Australia) in PBS (Sigma-Aldrich). Cultures were viewed with Olympus CK2 and IX70 inverted phase-contrast microscopes and photographed either using Nikon 600 cameras and Kodak TMY400 and EPH1600 film or by direct CCD capture (CCD-72EX; MTI, Michigan City, Indiana). For observation and immunolabeling, the PMC42-LA cells were grown in several formats. Cells were plated into 48-well culture dishes (TPP; Biocorp, Melbourne, Australia; 1800 cells/well) or onto 10-mm diameter acid-washed glass coverslips (Menzel, Germany) in 40-mm diameter tissue culture dishes (TPP) at $2 \times 10^{5}$ cells/plate. This gives a uniform seeding density over the entire culture surface. Alternatively, $100 \mu \mathrm{l}$ of cell suspension at $2 \times 10^{5} \mathrm{cells} / \mathrm{ml}$ was placed as a standing drop on either $10-\mathrm{mm}$ diameter glass coverslips placed in $30-\mathrm{mm}$ bacteriologic Petri dishes (Sarstedt, Adelaide, Australia) or $30-\mathrm{mm}$ tissue culture dishes (Nunclon). After 16 hours the dish was flooded with $2 \mathrm{ml}$ of culture medium. This produces a pavement-like plate of cells in the center of the coverslip, with a free edge that expands to cover the entire coverslip by 5 to 6 days (control) or 3 to 4 days (with $10 \mathrm{ng} / \mathrm{ml}$ EGF).

\section{EGF Treatment}

EGF (Becton Dickinson, Bedford, Massachusetts) was added to cultures at final concentrations of 1, 2, 10, and $50 \mathrm{ng} / \mathrm{ml}$ in RPMI containing 10\% FBS. AG1478, a tyrosine kinase inhibitor with selectivity for the EGF receptor kinase, was kindly supplied by Dr. A. Levitzki (Jerusalem University, Israel) and used at $2 \mu \mathrm{M}$ as previously described (Price et al, 1999).

\section{Immunofluorescence}

PMC42-LA cells were fixed in 4\% paraformaldehyde for 5 to 15 minutes or in methanol at $-20^{\circ} \mathrm{C}$ overnight, rinsed twice for 10 minutes in PBS, permeabilized with $0.1 \%$ Triton X-100 in PBS for 10 minutes, and blocked with $1 \%$ to $3 \%$ BSA in PBS for 30 to 90 minutes. For the time-course experiments, PMC42-LA cells were seeded at a density of 1800 cells/well in a 48-well plate and allowed to settle for 2 days. On days 2, 3, or 4 , EGF $(10 \mathrm{ng} / \mathrm{ml})$ was added to the culture medium. On Day 5 , the cells were fixed as above.

Primary antibodies diluted in PBS containing 1\% BSA were as indicated in Table 1. After three PBS washes, secondary antibodies (Table 1) were applied. Cells on coverslips were washed twice for a minimum of 10 minutes in PBS; a drop of Fluoroguard (BioRad, Sydney, Australia), Vectashield (Vector Laboratories, Burlingame, California), or 100 mg/ml DABCO (SigmaAldrich) in PBS was added to the specimens and a coverslip applied. In some cases these cells were briefly incubated with 4,6-diamidino-2-phenylindoleDAPI $(10 \mu \mathrm{g} / \mathrm{ml})$, propidium iodide $(2.5 \mu \mathrm{g} / \mathrm{ml})$, or Hoechst 6024 (Sigma-Aldrich; $0.1 \mu \mathrm{g} / \mathrm{ml}$ ) to label nuclei. Epifluorescence was viewed with an Olympus BX50 or IX70 microscope with selective FITC, Texas red, and 4,6-diamidino-2-phenylindole filters. Confocal images were collected using an Optiscan F900e system in a $512 \times 512$ pixel format.

\section{Western Analysis}

PMC42-LA cells were grown until $\sim 70 \%$ confluency and were either left untreated or treated with $10 \mathrm{ng} / \mathrm{ml}$ EGF for a further 4 days. Untreated MCF-7 and MDA-MB-231 cells grown under the same conditions were used as controls in some cases. The cells were harvested in chilled RIPA buffer (50 mm Tris- $\mathrm{HCl}, \mathrm{pH}$ 7.4, 1\% NP-40, 0.25\% sodium deoxycholate, $150 \mathrm{~mm}$ $\mathrm{NaCl}$ ) containing $1 \mathrm{~mm}$ EDTA, $1 \mathrm{~mm}$ phenylmethylsulfonyl fluoride, $1 \mu \mathrm{g} / \mathrm{ml}$ aprotinin, $1 \mu \mathrm{g} / \mathrm{ml}$ leupeptin, 1 $\mu \mathrm{g} / \mathrm{ml}$ pefabloc, $1 \mathrm{~mm}$ sodium orthovanadate, and 1 $\mathrm{mm}$ sodium fluoride (all from Sigma-Aldrich). Cell lysates were collected, and an aliquot was removed for 


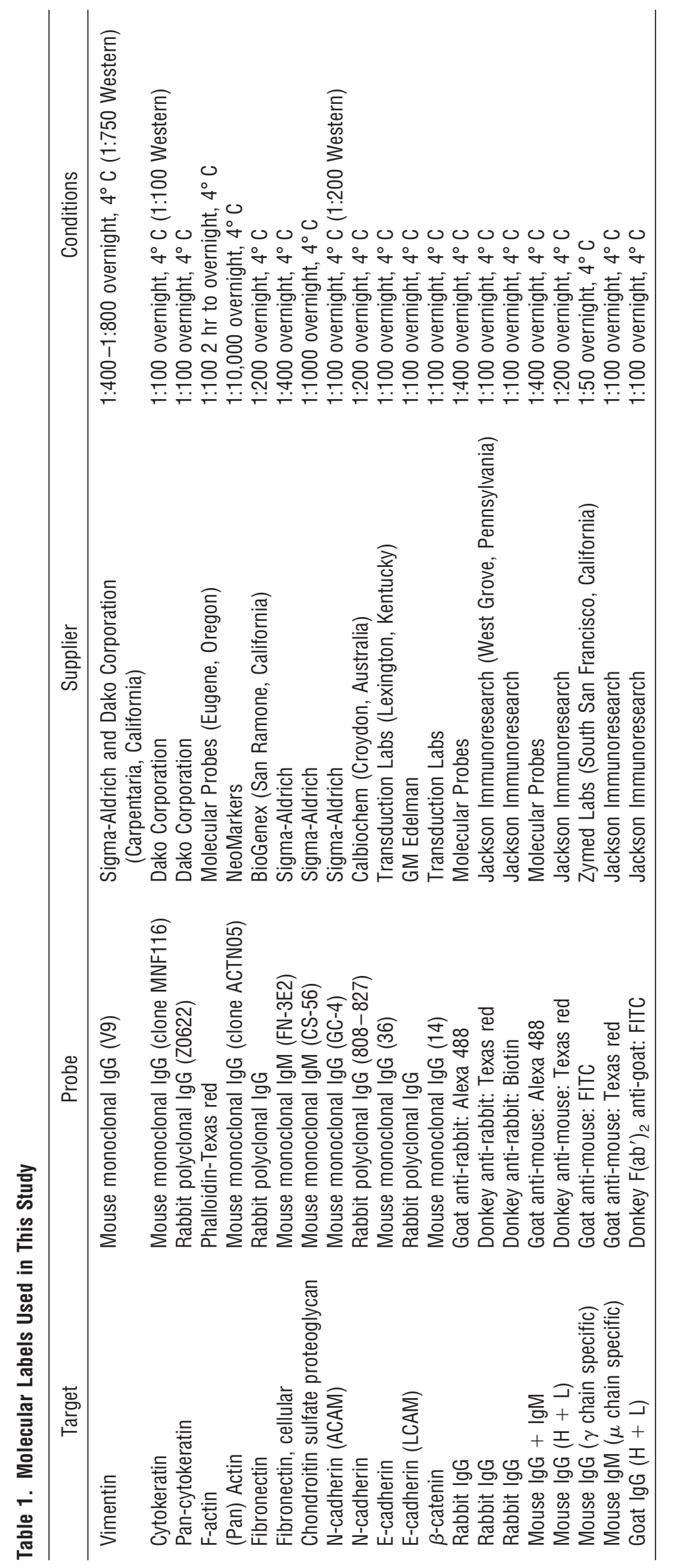


protein assay using the BCA protein assay kit (Pierce, Rockford, Illinois). Samples containing $20 \mu \mathrm{g}$ of protein were subjected to $10 \%$ SDS-PAGE and transferred onto Immobilon-P membrane (Millipore, Bedford, Massachusetts) ( $4^{\circ} \mathrm{C}$ and $100 \mathrm{~V}$ for 90 minutes). The membrane was blocked in PBS containing 5\% skim milk powder and $0.05 \%$ Tween 20 for 2 hours at room temperature and incubated with either mouse anti-vimentin (1:750), anti-cytokeratin (1:100), anti-Ecadherin (1:2500), or anti-N-cadherin (1:200) mAbs overnight at $4^{\circ} \mathrm{C}$. The membrane was washed and then incubated for 90 minutes with horseradish-peroxidase-conjugated anti-mouse secondary antibody (Pierce). Bands were visualized by chemiluminescence (Pierce) using x-ray film (Kodak- XAR, Coburg, Australia).

\section{Cell-Matrix Adhesion Assay}

To test the rate of adhesion to various ECM molecules, nontissue culture Terasaki plates were coated by exposure to molecules dissolved in either PBS or $0.2 \%$ acetic acid (collagen I only). Molecules tested were mouse laminin-1 (50 $\mu \mathrm{g} / \mathrm{ml})$, human plasma fibronectin $(20 \mu \mathrm{g} / \mathrm{ml})$, mouse collagen type IV (100 $\mu \mathrm{g} / \mathrm{ml})$, rat collagen type I (100 $\mu \mathrm{g} / \mathrm{ml}$; all from Boehringer-Mannheim/Roche, Castle Hill, NSW, Australia), and bovine vitronectin (5 $\mu \mathrm{g} / \mathrm{ml}$; from Dr. A. Underwood, CSIRO, Sydney, Australia). After 60 minutes of adsorption at $37^{\circ} \mathrm{C}$, unbound molecules were removed by washing with diluent, and free substrate sites were blocked by a 60-minute exposure to $1 \%$ BSA (Sigma-Aldrich; previously heated to $75^{\circ} \mathrm{C}$ for 5 minutes) in PBS. PMC42-LA cells, cultured with or without EGF for the previous 6 days, were lifted from culture with Versene, washed in RPMI/1\% FBS containing $10 \mathrm{~mm}$ HEPES, and allowed to recover for an hour at $37^{\circ} \mathrm{C}$, with trituration to prevent adhesion. Calcein AM (Live reagent; Molecular Probes, Eugene, Oregon) was added at 1:4000 dilution for the last 15 minutes to identify living cells. The cells were then diluted to $1 \times 10^{5} \mathrm{cells} / \mathrm{ml}$ and $10-\mu$ l aliquots were added to Terasaki wells and the cells were allowed to settle on ice for 10 minutes. The plates were then incubated for $15,30,60$, and 120 minutes at $37^{\circ} \mathrm{C}$. The total cells in the wells were then photographed under fluorescence on the Olympus IX70 microscope ( $\times 10$ objective, FITC filter). Then nonadherent cells were removed by inversion of the plates in warm PBS. After this, the retained cells were rephotographed. The images of the first photographs were scanned (Polacolor Insight) and psuedo-colored red, and the second set were psuedo-colored green using Photoshop 5.5. For each experiment type, 10 fields of 40 cells were chosen using the total cell (ie, red) image, and then the retained cell (ie, green) image was superimposed. Adherent (ie, yellow) cells were then counted. Statistical analysis was by unpaired $t$ test for each substrate at each time point (Prism v.3; Graphpad Software Inc., San Diego, California). A $p$ value greater than 0.05 was considered not significantly different.

\section{Chemomigration Assay}

Cell migration was assessed in either 48-well microchemotaxis chambers (Neuroprobe, Cabin John, Maryland) as previously described (Price et al, 1999) or in individual Transwell chambers (Corning, New York). In each case, cells were removed with PBS/EDTA (0.5 $\mathrm{mM}$ ), washed, and resuspended at $10^{6}$ cells $/ \mathrm{ml}$ in serum-free RPMI containing $0.1 \%$ BSA. For microchemotaxis chamber analysis, 56,000 cells (56 $\mu$ l) were placed in the upper chamber of the apparatus and the lower chamber contained either $0.1 \%$ BSA (negative control) or $10 \%$ FBS (chemoattractant). The upper and lower chambers were separated by an $8-\mu \mathrm{m}$ pore PVP-free polycarbonate filter (Poretics, California) coated with either collagen IV $(40 \mu \mathrm{g} / \mathrm{ml}$; SigmaAldrich) or collagen I (20 $\mu \mathrm{g} / \mathrm{ml}$, Cohesion, Palo Alto, California). Chambers were incubated for 6 hours, after which time the filters were removed, fixed, stained with Diff-Quik (Baxer Scientific, McGaw Park, Illinois), and mounted on glass slides. Nonmigrated cells were removed by wiping with a cotton swab. At least four random fields per well $(\times 20$ objective) were counted for quantitation of cell migration. Triplicate wells were performed in each assay, and the assay was repeated at least three times. The assessment of migration in individual Transwell chambers was performed as above, with the following modifications. Transwell membranes were coated on both sides with collagen IV $(50 \mu \mathrm{g} / \mathrm{ml})$ overnight at $4^{\circ} \mathrm{C}$. Then 100,000 cells were added to each Transwell, with $10 \%$ FBS being used as a chemoattractant. Migrated cells were counted in at least three random fields of vision. The assay was repeated three times with either single or duplicate samples. Statistical analysis (Prism v.3; Graphpad) was by unpaired $t$ test (microchemotaxis chamber) or ANOVA (Transwells).

\section{Acknowledgements}

Dr. Anne Underwood kindly supplied the vitronectin used in cell-ECM adhesion studies. The rabbit antibody to E-cadherin used in double labeling was kindly supplied by the lab of Dr. G. Edelman. We are grateful to Dr. Phillip Thompson for assistance in the preparation of this manuscript. We also are grateful to Drs. Julie Sharp and Elizabeth Williams for critical reading of the manuscript and to Dr. Williams for statistical help.

\section{References}

Ackland ML, Michalczyk A, and Whitehead RH (2001). PMC42, a novel model for the differentiated human breast. Exp Cell Res 263(1):14-22.

Batlle E, Sancho E, Franci C, Dominguez D, Monfar M, Baulida J, and Garcia De Herreros A (2000). The transcription factor snail is a repressor of E-cadherin gene expression in epithelial tumour cells. Nat Cell Biol 2(2):84-89.

Behrens J (2000). Control of beta-catenin signaling in tumor development. Ann NY Acad Sci 910:21-35. 
Birchmeier W and Behrens J (1994). Cadherin expression in carcinomas: Role in the formation of cell junctions and the prevention of invasiveness. Biochim Biophys Acta 1198(1): 11-26.

Birchmeier C, Birchmeier W, and Brand-Saberi B (1996). Epithelial-mesenchymal transitions in cancer progression. Acta Anat 156(3):217-226.

Boyer B, Valles AM, and Edme N (2000). Induction and regulation of epithelial-mesenchymal transitions. Biochem Pharmacol 60(8):1091-1099.

Bussemakers MJ, Van Bokhoven A, Tomita K, Jansen CF, and Schalken JA (2000). Complex cadherin expression in human prostate cancer cells. Int J Cancer 85(3):446-450.

Cano A, Perez-Moreno MA, Rodrigo I, Locascio A, Blanco MJ, del Barrio MG, and Portillo F, et al. (2000). The transcription factor snail controls epithelial-mesenchymal transitions by repressing E-cadherin expression. Nat Cell Biol 2(2):7683.

Cohen BD, Siegall CB, Bacus S, Foy L, Green JM, Hellstrom I, and Hellstrom KE, et al. (1998). Role of epidermal growth factor receptor family members in growth and differentiation of breast carcinoma. Biochem Soc Symp 63:199-210.

Duband JL, Monier F, Delannet M, and Newgreen D (1995). Epithelium-mesenchyme transition during neural crest development. Acta Anat 154(1):63-78.

Erickson CA, Tucker RP, and Edwards BF (1987). Changes in the distribution of intermediate-filament types in Japanese quail embryos during morphogenesis. Differentiation 34(2): 88-97.

Fafeur V, Tulasne D, Queva C, Vercamer C, Dimster V, Mattot V, and Stehelin D, et al. (1997). The ETS1 transcription factor is expressed during epithelial-mesenchymal transitions in the chick embryo and is activated in scatter factor-stimulated MDCK epithelial cells. Cell Growth Differ 8(6):655-665.

Franke WW, Schmid E, Winter S, Osborn M, and Weber K (1979). Widespread occurrence of intermediate-sized filaments of the vimentin-type in cultured cells from diverse vertebrates. Exp Cell Res 123(1):25-46.

Frixen UH, Behrens J, Sachs M, Eberle G, Voss B, Warda A, and Lochner D, et al. (1991). E-cadherin-mediated cell-cell adhesion prevents invasiveness of human carcinoma cells. J Cell Biol 113(1):173-185.

Gilles C, Polette M, Birembaut P, Brunner N, and Thompson EW (1997). Expression of c-ets-1 mRNA is associated with an invasive, EMT-derived phenotype in breast carcinoma cell lines. Clin Exp Metastasis 15(5):519-526.

Gilles C, Polette M, Piette J, Delvigne AC, Thompson EW, Foidart JM, and Birembaut P (1996a). Vimentin expression in cervical carcinomas: Association with invasive and migratory potential. J Pathol 180(2):175-180.

Gilles C, Polette M, Piette J, Munaut C, Thompson EW, Birembaut P, and Foidart JM (1996b). High level of MT-MMP expression is associated with invasiveness of cervical cancer cells. Int J Cancer 65(2):209-213.

Gilles C, Polette M, Zahm J, Tournier J, Volders L, Foidart J, and Birembaut $P$ (1999). Vimentin contributes to human mammary epithelial cell migration. J Cell Sci 112(Pt 24): 4615-4625.
Gilles C and Thompson EW (1996). The epithelial to mesenchymal transition and metastatic progression in carcinoma. The Breast J 2:83-96.

Hackel PO, Zwick E, Prenzel N, and Ullrich A (1999). Epidermal growth factor receptors: Critical mediators of multiple receptor pathways. Curr Opin Cell Biol 11(2):184-189.

Hales AM, Chamberlain CG, Dreher B, and McAvoy JW (1999). Intravitreal injection of TGFbeta induces cataract in rats. Invest Ophthalmol Vis Sci 40(13):3231-3236.

Harris AL, Nicholson S, Sainsbury R, Wright C, and Farndon $J$ (1992). Epidermal growth factor receptor and other oncogenes as prognostic markers. J Natl Cancer Inst Monogr 11:181-187.

Hatta K, Takagi S, Fujisawa H, and Takeichi M (1987). Spatial and temporal expression pattern of $\mathrm{N}$-cadherin cell adhesion molecules correlated with morphogenetic processes of chicken embryos. Dev Biol 120(1):215-227.

Hay ED (1995). An overview of epithelio-mesenchymal transformation. Acta Anat 154(1):8-20.

Hazan RB, Kang L, Whooley BP, and Borgen PI (1997). $\mathrm{N}$-cadherin promotes adhesion between invasive breast cancer cells and the stroma. Cell Adhes Commun 4(6):399-411.

Hazan RB, Phillips GR, Qiao RF, Norton L, and Aaronson SA (2000). Exogenous expression of $\mathrm{N}$-cadherin in breast cancer cells induces cell migration, invasion, and metastasis. J Cell Biol 148(4):779-790.

Hendrix MJ, Seftor EA, Seftor RE, and Trevor KT (1997). Experimental co-expression of vimentin and keratin intermediate filaments in human breast cancer cells results in phenotypic interconversion and increased invasive behavior. Am J Pathol 150(2):483-495.

Janda E, Lehmann K, Killisch I, Jechlinger M, Herzig M, Downward J, and Beug $H$, et al. (2002). Ras and TGF $\beta$ cooperatively regulate epithelial cell plasticity and metastasis: Dissection of Ras signaling pathways. J Cell Biol 156(2):299-314.

Liem KF Jr, Tremml G, Roelink H, and Jessell TM (1995). Dorsal differentiation of neural plate cells induced by BMPmediated signals from epidermal ectoderm. Cell 82(6):969979.

Liotta LA (1986). Tumor invasion and metastases: Role of the extracellular matrix. Rhoads Memorial Award Lecture. Cancer Res 46(1):1-7.

Lochter A, Galosy S, Muschler J, Freedman N, Werb Z, and Bissell MJ (1997). Matrix metalloproteinase stromelysin-1 triggers a cascade of molecular alterations that leads to stable epithelial-to-mesenchymal conversion and a premalignant phenotype in mammary epithelial cells. J Cell Biol 139(7):1861-1872.

McEarchern JA, Kobie JJ, Mack V, Wu RS, Meade-Tollin L, Arteaga CL, and Dumont $\mathrm{N}$, et al. (2001). Invasion and metastasis of a mammary tumor involves TGF-beta signaling. Int J Cancer 91(1):76-82.

Miettinen PJ, Ebner R, Lopez AR, and Derynck R (1994). TGF-beta induced transdifferentiation of mammary epithelial cells to mesenchymal cells: Involvement of type I receptors. J Cell Biol 127:2021-2036.

Minichiello J, Ben-Ya'acov A, Hearn CJ, Needham B, and Newgreen DF (1999). Induction of epithelio-mesenchymal 
transformation of quail embryonic neural cells by inhibition of atypical protein kinase-C. Cell Tissue Res 295(2):195-206.

Nakajima Y, Yamagishi T, Hokari S, and Nakamura H (2000). Mechanisms involved in valvuloseptal endocardial cushion formation in early cardiogenesis: Roles of transforming growth factor (TGF)-beta and bone morphogenetic protein (BMP). Anat Rec 258(2):119-127.

Newgreen DF and Minichiello J (1995). Control of epitheliomesenchymal transformation. I. Events in the onset of neural crest cell migration are separable and inducible by protein kinase inhibitors. Dev Biol 170(1):91-101.

Newgreen DF and Minichiello J (1996). Control of epitheliomesenchymal transformation. II. Cross-modulation of cell adhesion and cytoskeletal systems in embryonic neural cells. Dev Biol 176(2):300-312.

Newgreen DF, Kerr RS, Minichiello J, and Warren N (1997). Changes in cell adhesion and extracellular matrix molecules in spontaneous spinal neural tube defects in avian embryos. Teratology 55:195-207.

Nieman MT, Prudoff RS, Johnson KR, and Wheelock MJ (1999). N-cadherin promotes motility in human breast cancer cells regardless of their E-cadherin expression. J Cell Biol 147(3):631-644.

Nieto MA, Sargent MG, Wilkinson DG, and Cooke J (1994). Control of cell behavior during vertebrate development by Slug, a zinc finger gene. Science 264(5160):835-839.

Oft M, Peli J, Rudaz C, Schwarz H, Beug H, and Reichmann E (1996). TGF-beta1 and Ha-Ras collaborate in modulating the phenotypic plasticity and invasiveness of epithelial tumor cells. Genes Dev 10(19):2462-2477.

Page M (1989). Changing patterns of cytokeratins and vimentin in the early chick embryo. Development 105(1):97-107.

Parsons JT, Martin KH, Slack JK, Taylor JM, and Weed SA (2000). Focal adhesion kinase: A regulator of focal adhesion dynamics and cell movement. Oncogene 19(49):5606-5613.

Perou CM, Jeffrey SS, van de Rijn M, Rees CA, Eisen MB, Ross DT, and Pergamenschikov A, et al. (1999). Distinctive gene expression patterns in human mammary epithelial cells and breast cancers. Proc Natl Acad Sci USA 96(16):92129217.

Piek E, Moustakas A, Kurisaki A, Heldin C, and ten Dijke P (1999). TGF-beta type I receptor/ALK-5 and SMAD proteins mediate epithelial to mesenchymal transdifferentiation in NMuMG breast epithelial cells. J Cell Sci 112(Pt 24):45574568.

Price JT, Bonovich MT, and Kohn EC (1997). The biochemistry of cancer dissemination. Crit Rev Biochem Mol Biol 32(3):175-253.

Price JT, Tiganis T, Agarwal A, Djakiew D, and Thompson EW (1999). Epidermal growth factor promotes MDA-MB-231 breast cancer cell migration through a phosphatidylinositol 3'-kinase and phospholipase C-dependent mechanism. Cancer Res 59(21):5475-5478.

Ross DT, Scherf U, Eisen MB, Perou CM, Rees C, Spellman $P$, and lyer V, et al. (2000). Systematic variation in gene expression patterns in human cancer cell lines. Nat Genet 24(3):227-235.

Runyan RB, Potts JD, and Weeks DL (1992). TGF-beta 3-mediated tissue interaction during embryonic heart development. Mol Reprod Dev 32(2):152-159.
Savagner P, Boyer B, Valles AM, Jouanneau J, and Thiery JP (1994). Modulations of the epithelial phenotype during embryogenesis and cancer progression: Mammary tumorigenesis and malignant progression. Dickson $\mathrm{R}$ and Lippman $\mathrm{M}$, editors. Kluwer Academic Publishers, 229-249.

Savagner P, Yamada KM, and Thiery JP (1997). The zincfinger protein slug causes desmosome dissociation, an initial and necessary step for growth factor-induced epithelialmesenchymal transition. J Cell Biol 137(6):1403-1419.

Seshadri R, Raymond WA, Leong AS, Horsfall DJ, and McCaul K (1996). Vimentin expression is not associated with poor prognosis in breast cancer. Int J Cancer 67(3):353-356.

Somasiri A, Howarth A, Goswami D, Dedhar S, and Roskelley CD (2001). Overexpression of the integrin-linked kinase mesenchymally transforms mammary epithelial cells. J Cell Sci 114(Pt 6):1125-1136.

Sommers CL, Byers SW, Thompson EW, Torri JA, and Gelmann EP (1994). Differentiation state and invasiveness of human breast cancer cell lines. Breast Cancer Res Treat 31(2-3):325-335.

Sommers CL, Thompson EW, Torri JA, Kemler R, Gelmann EP, and Byers SW (1991). Cell adhesion molecule uvomorulin expression in human breast cancer cell lines: Relationship to morphology and invasive capacities. Cell Growth Differ 2(8): 365-372.

Sommers CL, Walker-Jones D, Heckford SE, Worland P, Valverius E, Clark R, and McCormick F, et al. (1989). Vimentin rather than keratin expression in some hormone-independent breast cancer cell lines and in oncogene-transformed mammary epithelial cells. Cancer Res 49(15):4258-4263.

Steinert PM and Roop DR (1988). Molecular and cellular biology of intermediate filaments. Annu Rev Biochem 57: 593-625.

Sternlicht MD, Bissell MJ, and Werb Z (2000). The matrix metalloproteinase stromelysin-1 acts as a natural mammary tumor promoter. Oncogene 19(8):1102-1113.

Sternlicht MD, Lochter A, Sympson CJ, Huey B, Rougier JP, Gray JW, and Pinkel D, et al. (1999). The stromal proteinase MMP3/stromelysin-1 promotes mammary carcinogenesis. Cell 98(2):137-146.

Tester AM, Ruangpanit N, Anderson RL, and Thompson EW (2001). MMP-9 secretion and MMP-2 activation distinguish invasive and metastatic sublines of a mouse mammary carcinoma system showing epithelio-mesenchymal transition traits. Clin Exp Metastasis 18:553-560.

Thompson EW, Paik S, Brunner N, Sommers CL, Zugmaier G, Clarke R, and Shima TB, et al. (1992). Association of increased basement membrane invasiveness with absence of estrogen receptor and expression of vimentin in human breast cancer cell lines. J Cell Physiol 150(3):534-544.

Thorne HJ, Jose DG, Zhang HY, Dempsey PJ, and Whitehead RH (1987). Epidermal growth factor stimulates the synthesis of cell-attachment proteins in the human breast cancer cell line PMC42. Int J Cancer 40(2):207-212.

Tomita K, van Bokhoven A, van Leenders GJ, Ruijter ET, Jansen CF, Bussemakers MJ, and Schalken JA (2000). Cadherin switching in human prostate cancer progression. Cancer Res 60(13):3650-3654.

Turner CE (2000). Paxillin and focal adhesion signalling. Nat Cell Biol 2(12):E231-E236. 
Vicovac L and Aplin JD (1996). Epithelial-mesenchymal transition during trophoblast differentiation. Acta Anat 156(3): 202-216.

Viebahn C (1995). Epithelio-mesenchymal transformation during formation of the mesoderm in the mammalian embryo. Acta Anat 154(1):79-97.

Viebahn C, Lane EB, and Ramaekers FC (1988). Keratin and vimentin expression in early organogenesis of the rabbit embryo. Cell Tissue Res 253(3):553-562.

Warn R, Harvey P, Warn A, Foley-Comer A, Heldin P, Versnel $\mathrm{M}$, and Arakaki N, et al. (2001). HGF/SF induces mesothelial cell migration and proliferation by autocrine and paracrine pathways. Exp Cell Res 267(2):258-266.

Welch DR, Steeg PS, and Rinker-Schaeffer CW (2000). Molecular biology of breast cancer metastasis: Genetic regulation of human breast carcinoma metastasis. Breast Cancer Res 2(6):408-416.

Whitehead RH, Bertoncello I, Webber LM, and Pedersen JS (1983a). A new human breast carcinoma cell line (PMC42) with stem cell characteristics. I. Morphologic characterization. J Natl Cancer Inst 70(4):649-661.
Whitehead RH, Monaghan P, Webber LM, Bertoncello I, and Vitali AA (1983b). A new human breast carcinoma cell line (PMC42) with stem cell characteristics. II. Characterization of cells growing as organoids. J Natl Cancer Inst 71(6):11931203.

Whitehead RH, Quirk SJ, Vitali AA, Funder JW, Sutherland RL, and Murphy LC (1984). A new human breast carcinoma cell line (PMC42) with stem cell characteristics. III. Hormone receptor status and responsiveness. J Natl Cancer Inst 73(3):643-648.

Yang J and Liu Y (2001). Dissection of key events in tubular epithelial to myofibroblast transition and its implications in renal interstitial fibrosis. Am J Pathol 159(4):1465-1475.

Zajchowski DA, Bartholdi MF, Gong Y, Webster L, Liu HL, Munishkin A, and Beauheim C, et al (2001). Identification of gene expression profiles that predict the aggressive behavior of breast cancer cells. Cancer Res 61(13):5168-5178.

Zavadil J, Bitzer M, Liang D, Yang YC, Massimi A, Kneitz S, and Piek E, et al (2001). Genetic programs of epithelial cell plasticity directed by transforming growth factor-beta. Proc Natl Acad Sci USA 98(12):6686-6691. 